\title{
Characteristic Properties of Cutting Fluid Additives Prepared from Amino Acids and Acid Chlorides
}

\author{
Shoji WATANABE*1, Hiroshi NAKAGAWA*2, Yoshihisa OHMORI*2, \\ Tsutomu FUJITA*1, and Masami SAKAMOTO*1 \\ *1 Department of Applied Chemistry, Faculty of Engineering, Chiba University \\ (Yayoicho, Inage-ku, Chiba-shi, $\mathbf{T} 263$ ) \\ *2 NEOS Central Research Laboratory \\ (Kohsei-cho, Kohga-gun, Shiga-ken, = $520-32$ )
}

\begin{abstract}
Various adducts were prepared by reactions of amino acids with acid chlorides, and examined for antirust and other characteristic properties. Aqueous solutions of $\mathrm{N}$-acyl leucine and $\mathrm{N}$-acyl glutamic acid salts with triethanolamine showed antirust and antiwear properties forward water-based cutting fluids to be quite satisfactory.
\end{abstract}

Key words : antirust activity, cutting fluid additives, antirust additives, water soluble cutting fluids

\section{Introduction}

A number of cutting fluids are used for various machining operations. Water-miscible cutting fluid has been a recent trend toward water-based fluids. It shows the advantages of low toxicity and excellent cooling capacity and also overcome problems associated with mineral oil-based products, such as unpleasant odor, oil mist formation and fumes at high temperature. However, for water-based cutting fluids to offer a practical alternative, they must possess good rust inhibiting, antiwear and antimicrobial activity. The authors previously reported that various derivatives of fatty acids have excellent rust inhibition properties for water-soluble fluids ${ }^{1)}$. In this short paper, new additives for water-soluble cutting fluids are described.

\section{Experimental Procedure}

2.1 $N$-(4-t-Butylbenzoyl)-leucine (3).

Leucine (1) $(2.6 \mathrm{~g}, 0.02 \mathrm{~mol})$ was suspended in a mixture of $20 \mathrm{~mL}$ of water and $20 \mathrm{~mL}$ of dioxane, and $0.8 \mathrm{~g}(0.02 \mathrm{~mol})$ of sodium hydroxide was added to form a solution of sodium leucine. While the solution was held at $0^{\circ} \mathrm{C}, 0.8 \mathrm{~g}(0.02 \mathrm{~mol})$ of sodium hydroxide in $10 \mathrm{~mL}$ of water and $3.93 \mathrm{~g}(0.02 \mathrm{~mol})$ of $t$-butylbenzoyl chloride (2) in $10 \mathrm{~mL}$ of dioxane were added dropwise at the same time and simultaneously with stirring over a period of about $60 \mathrm{~min}$. Stirring at $0^{\circ} \mathrm{C}$ was then continued for $3 \mathrm{~h}$. Water $(10 \mathrm{~mL})$ and $10 \mathrm{~mL}$ of $6 \mathrm{M} \mathrm{HCl}$ were added to the reaction mixture to keep $\mathrm{pH}$ 1. The precipitated crude crystals of $N-(4-t$-butylbenzoyl $)$ -leucine (3) was filtered off, washed with water and dried. The crude crystals were washed in $50 \mathrm{~mL}$ of $n$-hexane and $4.56 \mathrm{~g}$ of the pure acid were obtained $(79 \%$ yield $), \mathrm{mp} 157 \sim 158^{\circ} \mathrm{C}$. The crystals were recrystallized from a mixture of ethanol (7 vol) and water (3 vol). Analysis : Calculated for $\mathrm{C}_{17} \mathrm{H}_{25} \mathrm{NO}_{3}$ : C, $70.10 ; \mathrm{H}, 8.59$. Found : C, 70.07 ; H 8.56\%. Mass spectrum $(m / e)$ FAB Method, $(\mathrm{MH})^{+}=292$, theoretical value $\mathrm{MH}=292\left(\mathrm{C}_{17} \mathrm{H}_{25} \mathrm{NO}_{3}\right)$. This preparative method is modified from literature method ${ }^{2}$.

${ }^{*}$ Corresponding author : Shoji WATANABE 
Other products were prepared in the similar manner.

\section{$2 \cdot 2$ Testing methods}

$2 \cdot 2 \cdot 1$ Test method for corrosion resistance

Various test methods are known, and the authors have used the corrosion test with castiron chips as shown in reference No. 3. An aqueous solution of a mixture of compound (3) (1\%) and triethanolamine (2\%) was used for the following test. Cast-iron chips (JIS G 5501, FC-20) (2 g), which had been washed with benzene, were immersed in an aqueous solution $(5 \mathrm{~mL})$ of cutting fluids in a watch glass. After $10 \mathrm{~min}$, the solution was removed by tilting the watch glass. The rust-preventive effect (the amount of rust on the cast iron chips) was observed after 24, 48 and $72 \mathrm{~h}$. Ten points shows no appearance of rust. Seven points shows a slight appearance of rust. This method is based on the I. P. Corrosion Test 125/63 T ${ }^{3}$.

$2 \cdot 2 \cdot 2$ Friction coefficient

The friction coefficient was measured at $25^{\circ} \mathrm{C}$ by a pendulum-type oiliness and friction tester (Shinko Engineering, Co. Ltd., Tokyo) ${ }^{4}$ ).

$2 \cdot 2 \cdot 3$ Welding loads

The welding loads $\left(\mathrm{kgf} \mathrm{cm}^{-2}\right)$ were measured on a Soda-type four ball lubricating oil testing machine at $200 \mathrm{rpm}$. The machine was obtained from Shinko Engineering Co. Ltd., Tokyo ${ }^{5)}$.

$2 \cdot 2 \cdot 4$ Surface tension

The surface tension $\left(\mathrm{mN} \cdot \mathrm{m}^{-1}\right)$ was measured at $25^{\circ} \mathrm{C}$ using a Dü Noüy tensiometer.

$2 \cdot 2 \cdot 5$ Microbial activity tests

Agar $(20 \mathrm{~mL})$ was placed in a sharle having a diameter of $90 \mathrm{~mm}$, and solidified. A one $\mu \mathrm{L}$ drop bacterial culture was dropped on to the center of the agar and spread uniformly with a sterile, bent glass rod, and dried for $10 \mathrm{~min}$ at room temperature. On the center of the agar inoculated with this culture, $1 \mathrm{~mL}$ of the sample solution of the new cutting fluids was dropped, and the agar was kept at $30^{\circ} \mathrm{C}$. After 1,2 and $3 \mathrm{~d}$, the degree of increase of bacteria was observed. The assessment was as follows, “-” indicates no bacterial growth, "+" very little bacterial increase, "++" little bacterial increase, "+++" large bacterial increase. This method is modified from literature methods ${ }^{6), 7)}$. The above mentioned bacterial culture was prepared as follows ; a spent fluid (live fungi above $10^{7} \mathrm{~mL}^{-1}$ ) was collected from an industrial factory and the bacteria were cultured on a liquid broth for $48 \mathrm{~h}$ at $30^{\circ} \mathrm{C}$. The spent fluid contains microorganisms, such as Staphylococcus aureus, Desulfovibrio desulfuricans, Pseudomonas aeruginosa, Pseudomonas oleovorans, Klebsiella pneumoniae, Escherichia coli, Proteus mirabilis, and Fusarium sp. The bacteria content of the spent fluid was over $10^{7}$ $\mathrm{cm}^{-3}$.

\section{Results and Discussion}

It is known that many alkanolamines and their derivatives have been used as antimicrobial agent and corrosion inhibitors. For example, $2-(N$-amyl $)$-ethanolamine as both antimicrobial agent and corrosion inhibitors ${ }^{8}$, butanolamine and propanolamine as antimicrobial agents against a mixed flora of fungi and bacteria in cutting fluids ${ }^{9}$, the use of diethanolamine as antimicrobial agent ${ }^{10}$ ) and various ethanolamine derivatives as antimicrobial agent ${ }^{10}$ and corrosion inhibitors ${ }^{11), 12)}$ have all been reported.

The solubilities of higher fatty acids monoesters of alkanolamines to water were low in our experiments. We used amino acids in place of alkanolamines to increase the solubilities of the adducts of higher fatty acids. It was anticipated that monoamides of amino acids could be used as additives for water-soluble cutting fluids. Then, we prepared various $N$-acyl amino acids. For example, $N-(4-t$-butylbenzoyl)-leucine (3) was obtained from the reaction of leucine (1) with $t$-butylbenzoyl chloride (2). Aqueous solution of triethanolamine salt with (3) showed excellent corrosion resistance in a test with cast iron chips and antiwear proper- 
Table 1 Properties of Cutting Fluids Containing Various Adducts of Amino Acids with Acyl Chlorides.

\begin{tabular}{|c|c|c|c|c|c|c|c|c|}
\hline \multirow{3}{*}{ Products } & \multirow{3}{*}{$\mathrm{pH}$} & $\begin{array}{l}\text { Rust inhibition } \\
\text { test }\end{array}$ & \multirow[t]{3}{*}{$\begin{array}{l}\text { Friction } \\
\text { coefficient }\end{array}$} & \multirow{3}{*}{$\begin{array}{l}\text { Surface } \\
\text { tension } \\
\mathrm{mN} \cdot \mathrm{m}^{-1}\end{array}$} & \multirow{3}{*}{$\begin{array}{c}\text { Weld } \\
\text { load } \\
\mathrm{kgf} \cdot \mathrm{cm}^{-2}\end{array}$} & \multicolumn{3}{|c|}{$\begin{array}{c}\text { Antimicrobial } \\
\text { properties }\end{array}$} \\
\hline & & duration (h) & & & & 1 & 2 & 3 \\
\hline & & 72 & & & & & (d) & \\
\hline
\end{tabular}

Monoamides of amino acid (-NH-COR)

$R$

Leucine

$\begin{array}{crrrrrr}\mathrm{C}_{5} \mathrm{H}_{11} & 8.4 & 10 & 10 & 10 & 0.14 & 53 \\ \mathrm{C}_{7} \mathrm{H}_{15} & 8.4 & 10 & 10 & 10 & 0.12 & 42 \\ \mathrm{C}_{9} \mathrm{H}_{19} & 8.3 & 10 & 10 & 10 & 0.13 & 38 \\ \mathrm{C}_{11} \mathrm{H}_{23} & 8.8 & 10 & 10 & 10 & 0.13 & 39 \\ \mathrm{C}_{12} \mathrm{H}_{25} & 8.7 & 10 & 10 & 10 & 0.12 & 40 \\ \mathrm{C}_{14} \mathrm{H}_{29} & 8.8 & 10 & 10 & 10 & 0.12 & 39 \\ \mathrm{C}_{16} \mathrm{H}_{33} & 8.8 & 10 & 10 & 9 & 0.09 & 39 \\ t \text {-Butyl- } \mathrm{C}_{6} \mathrm{H}_{5} & 8.4 & 10 & 10 & 10 & 0.16 & 42\end{array}$

$\begin{array}{cccc}13.0 & +++ & +++ & +++ \\ 14.0 & ++ & ++ & ++ \\ 20.0 & ++ & ++ & ++ \\ 19.5 & +++ & +++ & +++ \\ 20.0 & +++ & +++ & +++ \\ 13.0 & ++ & ++ & ++ \\ 18.5 & ++ & ++ & + \\ 20.0 & +++ & +++ & +++\end{array}$

Glutamic acid

$\begin{array}{crrrrrr}\mathrm{C}_{9} \mathrm{H}_{19} & 8.1 & 10 & 10 & 10 & 0.10 & 32 \\ \mathrm{C}_{12} \mathrm{H}_{25} & 8.2 & 10 & 10 & 10 & 0.10 & 34 \\ \mathrm{C}_{14} \mathrm{H}_{29} & 8.5 & 10 & 10 & 10 & 0.09 & 30 \\ \mathrm{C}_{16} \mathrm{H}_{33} & 8.8 & 10 & 9 & 8 & 0.08 & 37 \\ - \text { Butyl- } \mathrm{C}_{6} \mathrm{H}_{5} & 8.0 & 9 & 8 & 7 & 0.16\end{array}$

$\begin{array}{lcccc}32 & 18.0 & +++ & +++ & +++ \\ 34 & 20.0 & +++ & +++ & +++ \\ 30 & 13.0 & ++ & ++ & ++ \\ 37 & 10.0 & +++ & +++ & +++ \\ 53 & 16.0 & +++ & +++ & +++ \\ & & & & \\ 32 & 18.0 & ++ & ++ & ++ \\ 32 & 20.0 & ++ & ++ & ++ \\ 33 & 10.0 & ++ & ++ & ++ \\ 37 & 20.0 & ++ & ++ & ++ \\ 49 & 15.0 & +++ & +++ & +++\end{array}$

Aspartic acid

$\begin{array}{crrrrrr}\mathrm{C}_{9} \mathrm{H}_{19} & 8.1 & 10 & 10 & 10 & 0.10 & 32 \\ \mathrm{C}_{11} \mathrm{H}_{23} & 8.2 & 10 & 10 & 10 & 0.10 & 32 \\ \mathrm{C}_{14} \mathrm{H}_{29} & 8.7 & 10 & 10 & 10 & 0.09 & 33 \\ \mathrm{C}_{16} \mathrm{H}_{33} & 8.7 & 10 & 9 & 8 & 0.08 & 37 \\ t-\text { Butyl- } \mathrm{C}_{6} \mathrm{H}_{5} & 8.2 & 9 & 8 & 7 & 0.16\end{array}$

Lysine

$\begin{array}{rrrrrrrrrrr}\mathrm{C}_{9} \mathrm{H}_{19} & 9.2 & 9 & 9 & 8 & 0.11 & 40 & - & ++ & ++ & ++ \\ \mathrm{C}_{14} \mathrm{H}_{29} & 9.3 & 9 & 8 & 7 & 0.10 & 43 & - & ++ & ++ & ++ \\ \mathrm{C}_{16} \mathrm{H}_{33} & 9.5 & 10 & 9 & 8 & 0.08 & 39 & 10.5 & ++ & + & +\end{array}$

Triethanolamine

(2\% aq. soln.)

$\begin{array}{lllll}10.3 & 7 & 6 & 5 & 0.21\end{array}$

70

$8.5 \quad+++\quad+++\quad+++$

Triazine type

antimicrobial agent

(1\% aq. soln.)

(0.5\% aq. soln.)

(0.1\% aq. soln.)

(0.05\% aq. soln.)

Water

Aqueous solutions of adduct $(1 \mathrm{~g})$, triethanolamine $(2 \mathrm{~g})$ and water $(97 \mathrm{~g})$ were used as the test solutions. The same results were obtained in the tests using either distilled water (hardness is 0 ) or city water (hardness about 80) in Chiba, Japan. 


\section{$\mathrm{CH}_{3} \mathrm{COOH}$}

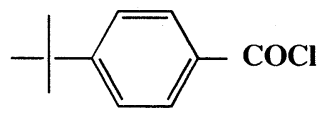

(2)
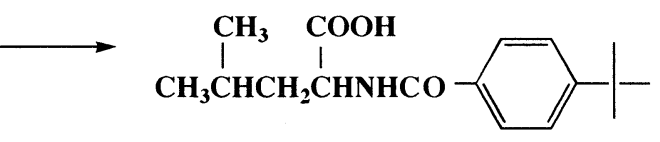

(3)

ties. Similarly, aqueous solutions of triethanolamine salts of other $N$-acyl leucine have excellent antirust properties and lubricity for water-soluble cutting fluids. $N$-Acyl glutamic acid and aspartic acid have a fairly good antirust properties. These characteristic properties are shown in Table 1. Water-soluble cutting fluids are easily degraded by microorganisms ${ }^{8), 13)}$. In this study, the authors examined the antimicrobial properties of our products in water-based cutting fluids. However, these compounds showed no antimicrobial activity.

From the above-mentioned results, $N$-acyl-leucine, $N$-acyl-aspartic acid and $N$-acyl-glutamic acid are good additives having both antirust and antiwear properties. These new additives described above for water-soluble cutting fluids were not previously known. Practical tests of these new additives are now in progress at our laboratory.

(Received Jul. 15, 1996 ; Accepted Sep. 11, 1996)

\section{References}

1) S. Watanabe, "Developments in Oils and Fats", Edited by R.J. Hamilton, Chapman \& Hall, London (1995) p. 95.

2) M. Takehara, I. Yoshimura, K. Takizawa, R. Yoshida, J. Am. Oil Chem. Soc., 49, 157 (1972).

3) I.S. Morton, Ind. Lubr. Tribol., 23, 57 (1971).

4) Nihon Junkatsu Gakkai, “Junkatsu Handbook, Yokendo Co. Ltd., Tokyo, Japan (1980) p. 381 (in Japanese ; English translation: "Handbook of Lubrication", Society of Japan Lubrication Engineers).

5) Nihon Junkatsu Gakkai, “Junkatsu Handbook, Yokendo Co. Ltd., Tokyo, Japan (1987) p. 394 (in Japanese ; English translation: "Handbook of Lubrication", Society of Japan Lubrication Engineers).

6) ASTM Standard Method D-3946-80 (American Society for Testing and Materials, Philadelphia, PA, (1980).

7) The Society for Antibacterial and Antifungal Agents, "Handbook for antibacterial and antifungal agent" (in Japanese), Gihoudo, Tokyo, Japan, (1986) p. 649.

8) E.O. Bennett, Lubr. Engng., 35, 137 (1979).

9) E.O. Bennett, M.C. Adams, G. Tavana, J. Gen. Appl. Microbiol., 25, 63 (1979).

10) J.E. Gannon, M.C. Adams, E.O. Bennet, Microbios, 23, 7 (1978).

11) U.S. Pat. 3429 909, 3764593.

12) HOSTACOR $B^{R}$ (A boric acid-alkanolamine condensation product) marketed by Hoechst, Technical Data Sheet, March 1992 (Printed in the Federal Republic of Germany).

13) I.N. Izzat, E.O. Bennet, Lubr. Engng., 36, 11 (1980). 


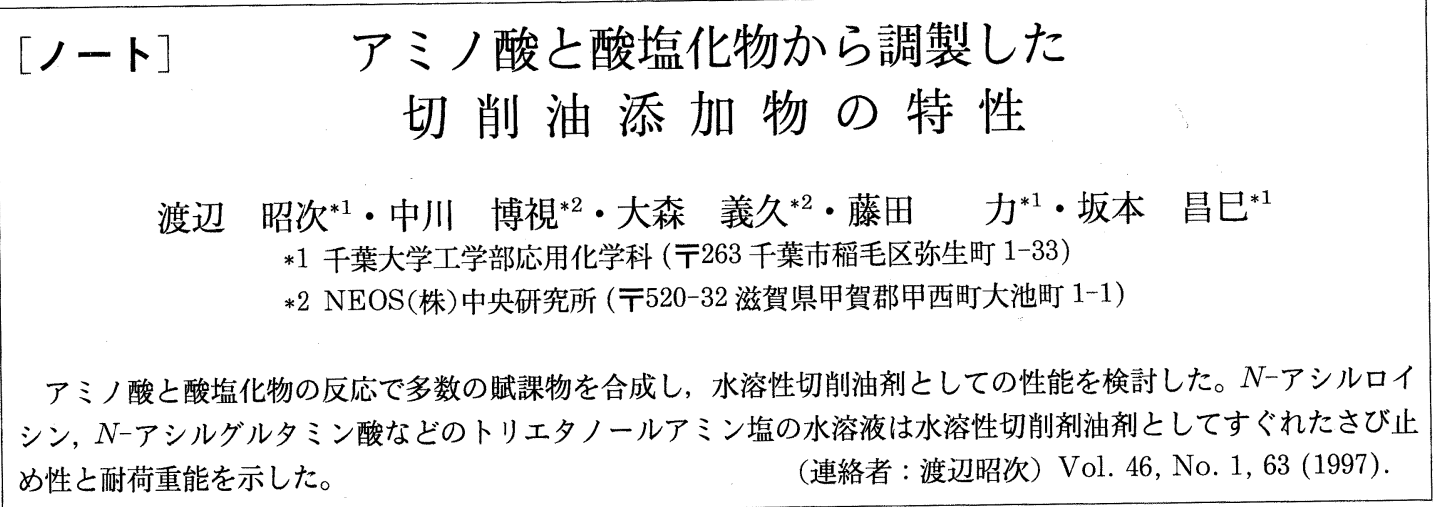

\section{書 評}

『塗装ハンドブック』

石塚末豊, 中道敏彦【編 集】

A 4 判 514 ページ
定 価 25,750 円
発 行 朝 倉 書 店
TEL 03(3260)0141, FAX 03(3260)0180

塗装は材料表面に塗料を塗り広げて塗膜を形成し，材料表面を保護すると同時に，材料を 美しくするのが目的である。また，この他にも耐熱性，帯電防止性，硬度や耐摩耗性，耐食性， 耐化学薬品性, 撥水性, 撥油性, 海中防污など特別な機能をもつ塗料および塗装が開発され ている。塗装はこれらの諸機能を後加工という比較的容易な手段で付与できる点で最近特に注 目されており，盛んに研究されている技術分野である。

本書は総論と各論から構成されており，まず総論では塗装概論による基本的な解説から, 㴽 装方法, 設計, 塗膜診断という具体的な塗装技術を紹介している。また，カラーコンセプト， カラーデザインなどの色彩計画, および安全, 衛生, 環境亡いう最近の視点からの解説も加え られている。各論では, 自動車, 鉄道, 橋, 船舶, 電気電子部品, 建築など多様な分野での用 途について，塗装技術や条件を詳しく述べている。

本書は塗装研究に携わる第 1 線の研究者・技術者によって書かれており，現在の塗装技術の 全体像を大変わかりやすく解説している。関連分野に関わっている方はもちろん，それ以外の 分野の方でも面白く読める内容となっており, ハンドブックとして是非お手元に置かれること を推薦したい。

(米山雄二) 